\title{
THE ONE AND DIFFERENTIATING PRINCIPLES OF HYPOSTASES IN PLOTINUS' METAPHYSICS
}

\section{Miroslav Vacura \\ Department of Philosophy, University of Economics, Prague}

\begin{abstract}
Three hypostases and their relations form the core of Plotinus' philosophical system. We claim that contrary to some interpretations, there are no overlaps or blurred borders between hypostases, and we demonstrate that mature Plotinus philosophy presents them as clearly defined and separated. This article begins by providing an overall overview of the structure of Plotinus' metaphysics. We then briefly characterize each of the hypostases to provide firm support for our claims. After this exposition, we discuss the relations of these hypostases and metaphysical differentiating principles, firstly providing an overview of other viewpoints then describing our proposed interpretation. The concluding remarks provide a comparison of our reading of Plotinus with the main interpretative principles of his work.
\end{abstract}

\section{INTRODUCTION}

Plotinus, ${ }^{1}$ the most important of the Neoplatonists, believed himself to be Plato's faithful successor and interpreter, who renewed his teachings and defended them against Gnostic and other forms of diversion. ${ }^{2}$ On the other hand, Plotinus's contemporaries already appreciated his originality and his creative development of Plato's thought (Porphyry 2017, §17, 19-20; Wallis 1972, 16). Although Plotinus is primarily a Platonic philosopher, we find many principles taken from the philosophy of Aristotle and other philosophical schools of thought based on his principles. Although he defended himself against many of these, it did not prevent him from incorporating elements of other philosophical systems into his own work. Plotinus' philosophy, though based on the ideas of his predecessors, thus forms his own closed and structured system, and some authors describe the works of other Neoplatonists as footnotes to the Enneads in comparison to Plotinus' originality.

In his own philosophical work, Plotinus often relied only on short passages of Plato's text (sometimes taken out of context), and some parts of Plato's teachings are completely omitted from his philosophy (political philosophy and mathematics). He also makes virtually no attempt to find basic, ethically relevant definitions in Plato's 
early dialogues (Wallis 1972, 18). This is also the case with Plotinus' theory of three hypostases, which, in various places, reveals that he was clearly inspired by different passages from Plato's dialogues. Still, it seems that this theory is itself one of the most original of Plotinus' contributions to Plato's legacy. ${ }^{3}$

Three hypostases form the core of Plotinus' philosophical system, and the philosopher devotes considerable attention to comprehensive description of each of them and their relations. Still, his specific style of writing makes interpretation difficult. Indeed, Porfyrios reports that Plotinus was not overly systematic in his writing, instead choosing topics "that occurred to him," taking "his topics from questions he was engaged with at the time" and not even giving titles to his treatises (Porphyry 2017, §4, 10, $5,61, \S 4,18$ ). He also never read the text once he had written it because of his poor eyesight, so no corrections were made. His handwritten text was also difficult to read because "He wrote without aiming for beauty in the individual letters, without keeping syllables distinct, and without any concern for spelling" (Porphyry 2017, §8, 4). All these facts make interpretation of Plotinus' philosophy challenging, and some of his fundamental concepts are still debated today.

This is also the case with three hypostases which form the core of Plotinus' philosophy, and the case in terms of their relations and differentiations - the problem that is central to this study. In the next section of the article, we firstly provide an overview of the structure of Plotinus' metaphysics and then briefly describe the three hypostases (the One, the Intellect and the Soul) in the following three sections. Section six discusses their relations and differentiating principles, firstly providing an overview of other interpreters' views, then describing our proposed interpretation. Section seven concludes the article with some final remarks and suggestions for future research.

\section{ARCHITECTURE OF PLOTINUS' METAPHYSICS}

Plotinus' metaphysics is hierarchical in nature and is based on the idea of multiple levels, layers or the "chain of being." However, when we talk about Plotinus" metaphysics, we inevitably encounter difficulties stemming from the limitations of our language: as O’Meara (1996, 66-67) points out, expressions such as "hierarchy" or "chain of being" only come later, and we cannot find them in Plotinus' text. Therefore, if we use them in the context of the Plotinus system, we must be aware of the limits of their meaning. When describing this hierarchy, the same author prefers, where

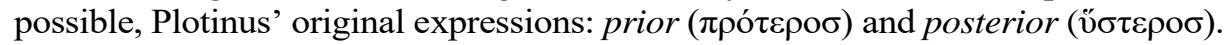

In Aristotle's philosophy (which we believe gave Plotinus inspiration here), the relationship between accidents and substance was a relationship of dependence and conditionality. ${ }^{5}$ Without substance, there can be no accidents. Only with substance (e.g., a thing) can there be an accident (e.g., its property or whiteness). If the substance ceases to exist, all accidents associated with it cease to exist as they are dependent on it. Substance is, therefore, understood using Plotinus' terminology as prior, and accidents are understood as later. Construction of a tiered metaphysical system with this type of relatedness and dependency "as to its being" also reflects Plotinus intention in terms of the order in which levels of being follow one another, where the previous one is always prior in this sense, and the following one is later. What it represents is, 
therefore, a relationship of ontological dependence and founding, which iteratively repeats.

So, what levels does Plotinus' metaphysical system define? Its starting point is the relationship between soul and body. In their case, we can ask whether there is a relationship of ontological dependence - whether one of them is prior in the ontological sense and is the foundation of the other which depends on it. Plotinus' Ennead IV.7 lists various arguments to prove that the soul is more prior than the body. This reflection, in its full development, not only concerns everything physical (the material world and the world of bodies) but also leads to reflections on the nature of the soul itself, plural souls, and their species and interrelationships. The text of Ennead IV.4-5 is then devoted to the relationship between physical and spiritual. Regarding the spiritual world, Plotinus accepts Aristotle's teachings on various kinds of soul (the vegetative soul of plants and the sentient soul of animals etc.) but also Plato's conception of the world soul, which also includes particular individual souls (Robinson 1967).

However, according to Plotinus, the soul cannot stand at the highest level of the ontological hierarchy, and we must, therefore, ask whether there is anything more prior from which the soul's being would be derived and ontologically dependent on. Plotinus, again inspired by Plato and Aristotle, asserts that the ontological superior to the soul is the intellect. The intellect (voṽ $\sigma$ ) is ontologically prior to the soul, which is dependent on it in its being. Given the lack of clarity over what is meant by intellect in this context, we will return to its explanation on the following pages. For the time being, we can regard it as Aristotle's divine reason or Plato's world of ideas (Menn 1992).

Even at the level of the intellect, this type of questioning cannot be stopped according to Plotinus and Aristotle for whom divine reason (the first immovable mover) is, in this context, the most prior entity. Plotinus, however, believes that here again it is possible to ask whether there is something more prior on which the intellect's being is founded. An intellect, encompassing a certain multiplicity and diversity, cannot just exist by itself, independent of anything else. Multiplicity presupposes unity for Plotinus, and unity is always ontologically prior to multiplicity. More prior than the intellect (and what the intellect "in its being" is derived from and ontologically depends upon) is the One, absolute and undivided unity.

The One, as already obvious from Plotinus' chosen term, does not include any multiplicity or diversity. It corresponds to Plato's idea of goodness which transcends all other ideas. Plotinus' the One stands outside the ontological framework of everything

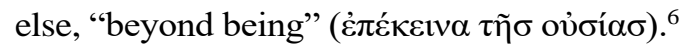

These three levels underlying or founding the sensory world - Soul, Intellect and the One - are called Plotinian hypostases ( (vंđó) something else, underpins it, its foundation, fundament). ${ }^{7}$ The basic structure of Plotinus' metaphysical system is depicted in a simplified way in Figure 1. The totality of the whole being is thus founded (in the last instance) on the One, in which everything is ontologically based and from which everything springs or, to use Plotinus' term, emanates (see below). 


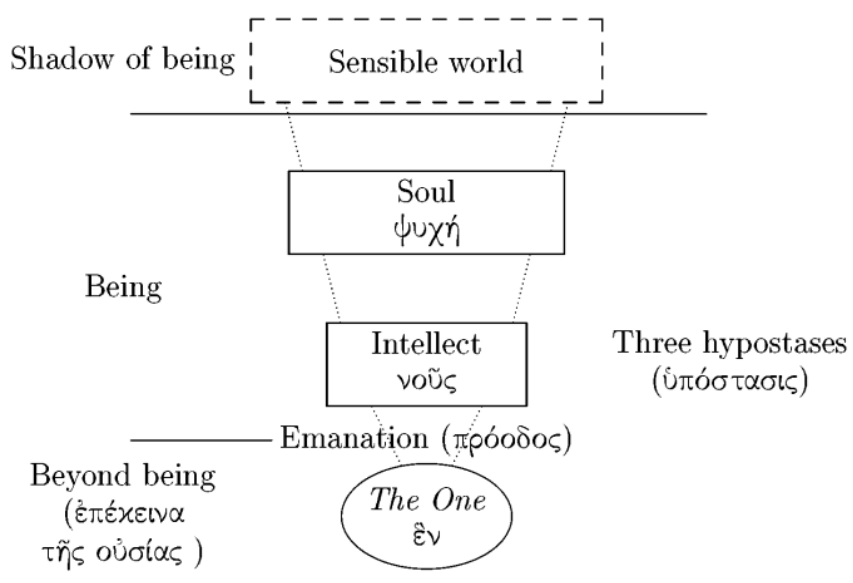

Figure 1: Structure of Plotinus' metaphysical system

To summarize: Plotinus' metaphysical system is based on the theory of three

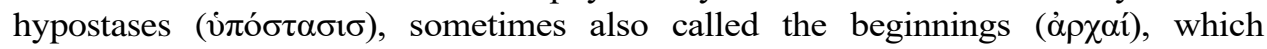
underpin the sensory, material world. The hierarchical ontological arrangement of reality thus comprises four levels - three hypostases and the sensory world (Corrigan 2005, 7):

- One (ृ̀v)

- Intellect (voṽ $\sigma)$

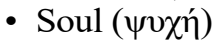

- The sensory world.

This arrangement is primarily hierarchical in terms of ontological dependence: the One is the beginning and the foundation of everything; the Intellect is founded on the One; the Soul is founded on the Intellect; and the sensory world of nature is the result of the Soul's influence on the matter in accordance with the Intellect. Every ontological level is a reflection or image of the one above it in the hierarchy. The fundamental question here is whether these metaphysical levels are clearly delimitated - whether they are strictly separated or (as some interpreters believe) they somehow overlap, and their borders are not clear but fuzzy. Before answering this question, let us now briefly look at each individual hypostasis.

\section{THE ONE}

Interpretation of the One is complicated by the fact that, according to Plotinus, it is in essence inexpressible and inexplicable. It is impossible to say what One is (V.3.13.7, 14.1). ${ }^{8}$ Any interpretation is inadequate and efforts to capture it verbally can never be successful. Yet, as Bussanich $(1996,38)$ notes, Plotinus is constantly talking 
about the One, making fundamental ontological claims about its nature. The indescribability of the One, however, has a reason, mainly due to the fact that the One itself (as an ontological basis of the Intellect) is the basis of all thought, the conceptual grasping of reality and, therefore, of speech. As a prerequisite for the possibility of thinking and speaking, the One is not fully conceivable and utterable (VI.6.13.44, VI.9.4.1; Banner 2018, 178).

One possible way to at least say something indirectly about the One is to talk negatively - to say what the One is not (V.3.14.6). By the same token, "the One" cannot be understood as a positive predicate. Its meaning is primarily to emphasize the negation of any plurality. Banner $(2018,180)$ calls Plotinus' the One "a transcendent monad" being "the unity as such". This is why Plotinus (1992, V.5.6.26) also praises the Pythagoreans who called Apollo the highest deity $(\alpha=$ no; $\pi \mathrm{o} \lambda \lambda \alpha \dot{\alpha}=$ many). Thus, some interpreters understand both the One and the Good (sometimes used synonymously) as negative definitions (VI.6.13.44, VI.9.4.1; Wallis 1972, 59).

Moreover, the One cannot be adequately approached by discursive thinking. A suitable way of considering at least some aspects of the One is through immediate, intuitive understanding or insight ( $(\pi \alpha \rho o v \sigma i ́ \alpha)(V .5 .2 .15$, VI.9.4.1). Such knowledge obviously takes the form of a mystical vision rather than intellectual knowledge in the ordinary sense. It does not mean, however, that Plotinus is an irrationalist, referring solely to this nonrational form of cognition. Note that here we only talk about the One - the metaphysical foundation of reality in its entirety, which is beyond being and beyond thought. If we are to gain access to it, then possibilities other than this mystical vision are, according to Plotinus, difficult to imagine. ${ }^{9}$

To deepen our understanding of the One, it may also help us to reflect on what comes from the One and what is produced by it (III.8.10.34, II.33-39, V.3.14.1). It is first and foremost about getting to know the Intellect, an intelligible world that is the immediate product of One in the ontological hierarchy. Each product is an imperfect image of its originator, so through knowledge of the products of the One, we can gain knowledge of the One, albeit in an imperfect way. Therefore, when we speak of the One using terms at lower ontological levels that are only adequate for use at these lower levels, we do not say something false, but due to the inadequate use of these terms at a higher ontological level, we must be mindful that their validity is only analogous or metaphorical (VI.8.8.1, VI.9.3.49).

Knowledge of the One is the ultimate goal of all philosophy (I.3.1.2). Certainty of the existence of the One and also of the Intellect is evident at a certain level of philosophizing, and there is no need for discursive thinking to prove it, but it is a starting point for further inquiries. This is why Bussanich $(1996,40-41)$ also calls Plotinus a "mystical empiricist." Knowing the One also means being identical to the One in some sense (VI.7.36).

Plotinus also stresses that the One is not the first in the sense of being the first in

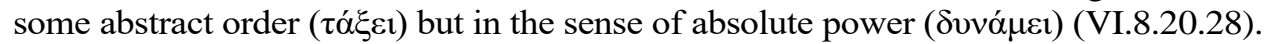
Any ordering presupposes a certain arrangement of members that have something in common yet also certain differences (V.5.13.21). Primacy of the One certainly cannot 
be understood in this sense (O'Meara 1996, 77). The One is to be understood as clearly separated from everything else (with no overlap) and on a completely different metaphysical level.

Furthermore, the One cannot be understood as an object or entity (II.9.1.1, VI.7.38.4, VI.9.5.29). The One does not relate to anything else, but other things may relate to the One (VI.8.8.12, VI.9.6.40). Thus, the One is independent of anything else, self-sufficient or even "beyond self-sufficiency" (VI.7.32.9, V.3.17.14). The One is simple, i.e., without parts or internal relationships. ${ }^{10}$ It is not determined in any way

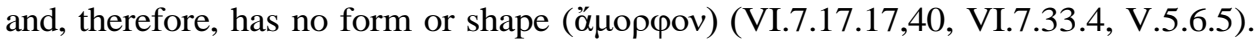
Even in this sense, it is "beyond being."

An absence of form implies that the One is unlimited and without boundaries

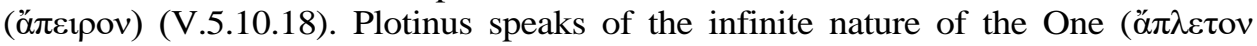

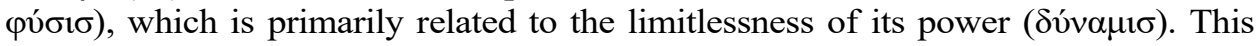
power is manifested above all in the production of the Intellect, the second hypostasis relating to the intelligible world (V.4.1.23, V.5.10.18, VI.9.6.10, II.4.15.17, VI.9.6.7, V.5.11.1).

The One is perfect because of its independence from anything else and the simplicity that results from its own nature (if we consider the word nature to be applicable) (V.1.6.38, V.6.2.13). Its perfection is also connected with Aristotle's

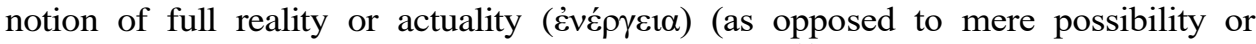
potentiality). The One is, therefore, all-encompassing. ${ }^{11}$

We can thus conclude our analysis of the metaphysical nature of the One by observing that with regard to Aristotle's classification of categories of being, the One does not fall into either of these classes. In terms of this classification, it stands, again, beyond being.

The One is sometimes referred to as the Good by Plotinus and thus establishes an area of ethics. The One is, therefore, not only the beginning of all being ( $\dot{\rho} \chi \eta$ ) but also the ultimate goal and the purpose of everything ( $\tau \varepsilon \dot{\lambda} \sigma \sigma)$. On the other hand, the One itself has no needs or desires; it is completely free of any need and is, therefore, good only for others, not for itself. ${ }^{12}$ Plotinus, however, goes even further in some places of his text, conceptualizing the One as not only self-sufficient but also "beyond" self-sufficiency and thus "beyond" the Good (V.3.17.12, VI.9.6.55).

The One is, therefore, the ultimate good and the goal - desired because it is good and (objectively) is the Good (not the other way round, i.e., good because it is desired) (VI.7.19.1, VI.7.25.16). According to Plotinus, this characteristic of its ultimate purpose is related to the absence of any form or specific quality ascribable to the One (V.5.13.1, V.3.11.23). Wallis $(1972,59)$ draws attention to the paradoxical similarity between the One on one side and formless matter on the other - polar opposites in Plotinus' ontological hierarchy. The One is as it is out of necessity, but this does not limit its absolute freedom according to Plotinus (VI.8.10.15).

\section{One and the production of other levels of reality - emanation}

In the introduction, we have already shown that Plotinus' metaphysical conception involves the hierarchical organization of reality underpinned by the One. 
But what is the relationship between the One and other levels of being? We have seen that the One has no external relations to anything else; it is completely independent, self-sufficient and even beyond being. If we use terms such as "principle" and "cause" etc. to describe the relationship of the One to other levels of being, we must be aware (as has already been pointed out) that use of such terms is primarily suitable for lower levels of reality. It is possible to use these terms only in an analogous or metaphorical way to describe the nature of the relationship of the One to everything else, while these concepts can never fully express its true nature.

The One is related to other entities in two ways. Firstly, the One is the cause or precursor of everything else; secondly, the One is the goal or purpose, i.e., it is the

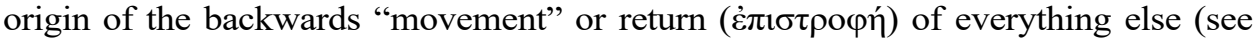
Figure 2). The first type of "activity" explains the existence and creation of the world (both intelligent and, in the next order, also material). The second "activity" is the basis of the meaningfulness of the world and, consequently, of ethics.

The uniform (the One) is the "precursor" or the cause of everything that is nonuniform, compound and complex etc.13 But how can unity give rise to multiplicity? Plotinus claims that the product is always less perfect than the producer (or the predecessor), so if, in this case, the predecessor is the One (fully uniform), the product must be less perfect, that is, non-uniform. The product must, therefore, contain a certain plurality and variety (V.3.15.1, VI.7.8.17). This product is primarily Intellect, an intelligible world of varying ideal forms. On the other hand, the One must, in some form, contain a unified multiplicity of Intellect (and other derived degrees of reality) (V.2.1.2, VI.8.18.32). Wallis $(1972,20,49,60)$ points out that within the Plotinian system, such assumptions are fully consistent since, from a Platonic point of view, it can be argued that although multiplicity is always a non-uniform plurality, the form or idea of multiplicity is itself a unity (II.4.9.5, III.6.17-18). We can only think of the relationship between the Intellect and the One analogously. Thus, although the One is

Intellect, Soul, sensible world

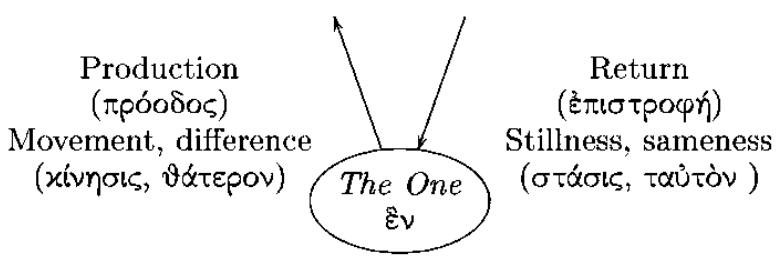

Figure 2: Production and return in Plotinus' metaphysical system

the source of everything, it is itself not an entity (V.2.1.1, VI.7.32.12). It is also not a simple summary of entities and cannot be unified with them: "... [A] 11 things are from a principle. And this is no more all things, nor any of them" (III.8.9.39). This again implies that the One as a hypostasis is clearly distinct from other entities at other metaphysical levels, with no overlaps, while also being the source or principle of them 
all. According to Plotinus, we should treat the One "... as that cause, which is above these things, while not being identical to them" (V.5.13.17).

Returning to the question of producing other levels of reality from the One, Plotinus uses a series of metaphors by way of an explanation, such as heat radiating from a fire, cold emanating from snow or light from the sun (V.1.6.28, V.3.12.39, V.4.1.23). The term "emanation", which is derived from the expression used inter alia for the flow of light from the sun (lat. emanare), is often used to express the nature of this productivity of the One. We should point out that all these comparisons must again be understood only metaphorically, especially because, e.g., the sun is spatially localized, and the luminous flux has certain spatial (and possibly temporal) characteristics from which we must abstract. At the same time, it is important to realize that Plotinus sees light in the sensory world as an immaterial force, unlike Stoics who considered it to be a material force or Aristotle who interprets it as an accidental modification of air. ${ }^{14}$

The principle of the first degree of emanation (production of the Intellect from the One) is tolma ( $\tau$ ó $\lambda \mu \alpha)$, an expression that, according to Armstrong (1967, 243), Plotinus probably obtained from the neo-Pythagoreans, who used this term to describe the Dyad, "because it was the first to separate from the monad." 15 It is a kind of indeterminate principle of multiplicity, an unformed desire for separate existence, a desire to "be as such" - a regrettable desire because it is a desire for something less than the Good. This initial form of the tendency towards diversity manifests itself at other levels of reality in different ways. For example, in the case of the soul, it is an inner unrest, a desire for constant activity, a movement for movement's sake or a continuous sequence of successive events and experiences.

An essential characteristic of emanation (and all other lower levels of reality originating from higher ones) is that this production does not diminish the producer, the producer's internal strength or energy (III.8.8.46, III.8.10.1). At the same time, everything that can be produced is produced. At each of the lower stages there is a kind of perfect realization of everything that is at all possible. Nothing remains unrealized; mere possibility. Thus, although Plotinus says in one place that the One could produce some other universe, he immediately rejects this idea because it is not possible for such a thing to be produced once Everything exists (V.5.12.40). Thus, emanative production creates the fullness of existence at every level of reality. After this, the productive power descends to the next (lower) level of reality and again produces it fully. Each successive level is more imperfect and unspecified; just a reflection of the previous level. Production ends at the level of a dark, formless matter that has no characteristics (IV.8.6, V.2.2.1). Thus, everything that can exist is produced. We can see that the expression "everything" not only has a descriptive meaning as the sum of randomly existing entities, but its meaning is stronger: nothing could possibly exist beyond what already exists; everything that could ever exist does so and is part of the full reality of entities that the One has produced and which could ever have been produced. Thus, reality and possibility are, at this level, unified. ${ }^{16}$

Obviously, if everything that can be real is produced, then (at least at the level of the sensory world) there will be beings and things resembling (to varying degrees) their intelligible ideal essences, and reflecting to a different extent the Good as such. ${ }^{17}$ That 
which is produced by the One, therefore, even includes what we would regard as evil. Yet Plotinus maintains the idea of the whole of everything as perfect and presents the metaphor of a painting whose colors may not all be beautiful but which, as a whole, may still be beautiful (III.2.11). This metaphor, which (as far as we know) comes from Plotinus, has been extremely influential in the history of philosophy.

The very explanation of emanation from the One comes from observing (re)production at lower levels of reality. The perfect One overflows with its power, resulting in emanative production (V.2.1.7). Wallis $(1972,61)$ associates this process with the classical principle transmitted by various philosophical traditions, which is expressed in the scholastic motto "good diffuses itself" (bonum diffusivum sui). In other words, perfect entities do not keep their perfection for themselves but spread it, thus creating an external image of their inner perfect state. Plotinus (1992, V.1.6.37) states this quite explicitly: "[A]ll things, as soon as they are perfected, generate"). Similarly, we can understand the metaphysical cause of the emanation of the One (Plato 1989b, 29e-30a). ${ }^{18}$ To illuminate this character of the One, Plotinus sometimes uses the term " $\alpha \varphi \theta$ oví $\alpha$ " to describe it, which can be translated as a complete absence of selfishness or envy. ${ }^{19}$

Another similar starting point for an explanation of the nature of emanation is analysis of the contemplative state that Plotinus attributes to beings at different ontological levels. Individual souls are capable of contemplation, and world soul (nature) is in "sleeping contemplation" (III.8.4.15). At the level of intelligible reality, individual intelligible entities and the Intellect itself as a hypostasis (divine reason) are also contemplative. This contemplation, a self-centered, inner "activity", is a source of inner energy and power for Plotinus (1992, VI.6.1.4) at every ontological level. External production (creative power) is the result of an abundance of this inner energy at every level.

Thus, according to Wallis $(1972,62)$, the One can also be understood to be in a state of "hyper-contemplation," which is the cause of an excess of internal energy, leading to the emanative production of other levels of reality. It should be emphasized, however, that this production does not happen according to any preliminary consideration, intention or plan (III.2.2.8, V.8.7.1) but is completely spontaneous (III.8.4.9), without any desire, will, movement or change (V.1.6.25, V.3.12.20). It also takes place outside of time, so it is not a process with a beginning and a course. Rather, Plotinus tries to capture the relationship of dependence and derivation using these expressions.

These characteristics of producing lower levels of reality then apply not only to the One but also to productions at other levels of the ontological hierarchy, i.e., production of the Soul from the Intellect and production of the sensual world from the Soul. Each stage of this production is spontaneous and without any intention, so this productive activity cannot be compared to the work of a human craftsman (IV.3.10.13, IV.4.11-13). Plato's analogy in the Timaeus dialogue must, therefore, be understood in the sense that the world is as good as if it were created on the basis of the best possible consideration. ${ }^{20}$ 


\section{THE INTELLECT}

Many characteristics of the Intellect are close to what we have already mentioned in connection with the One (Bussanich 1996, 44). The intellect is perfect, lives a perfect life, is fully real, self-sufficient and also possesses infinite power. ${ }^{21}$ In contrast, unlike the One, the Intellect is not uniform. It is by nature full of multiplicity, division and determination. There is, therefore, no overlap between the One and the Intellect.

On the other hand, the Intellect is in some respects similar to the Soul, and Plotinus sometimes uses the term "voṽ $\sigma$ " for both. The distinction between Intellect and Soul is often interpreted by Plotinus on the basis of their accessibility: whereas the intelligible world of the Intellect is the subject of thinking in the form of vónбı (i.e., the immediate intellectual perception of ideas that are not structured in time), thinking at the level of the Soul is discursive and structured in time; it is a process (III.7.11.20). This difference is due to the fact that the Intellect, as a hypostasis, is eternal or timeless (although all hypostases are eternal). Time only enters Plotinus' ontological system later at the level of the Soul, which is temporal (although it eternally exists as a hypostasis) (III.7.11.23).

The Intellect, an intelligible world, consists of ideas or forms, whether as species at different levels of generality or mathematical ideas (Plotinus speaks of them as the first or true beings) (V.9.5.18). However, these individual ideas are for Plotinus individual living and thinking beings (though thinking in a non-temporal sense), which at the same time, being ideas, can be the subject of thought. They are, therefore, the subject of thinking (not only human) but, above all, the subject of self-thinking by the Intellect itself. The essence of the Intellect is then identical to the essence of its content: "For if its substantiality is other than its thinking, what it thinks is different from it, and its substantiality will be without thought, and once again, it will be in potency, not in actuality." 22 This establishes an Intellect in which thinking is identical to its object i.e., Intellect both in terms of its parts and individual ideas, and as a thinking whole itself: "But if thinking comes from itself and out of itself, it is itself what it thinks." 23

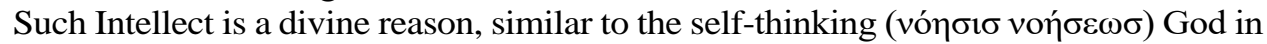
Aristotle's understanding. ${ }^{24}$ However, Blumenthal $(1996,94)$ emphasizes that while in Aristotle's conception divine reason really only thinks its own thinking without any particular content, in Plotinus' case, the Intellect thinks its own ideal content; its internal diversity. By its thinking, the Intellect makes this ideal content real, and, at the same time, it becomes identical to its content through this thinking: "In fact, it is clear that Intellect, being real, thinks Beings and causes them to exist. It is, therefore, these Beings." ${ }^{25}$ Plotinus (1992, V.9.5.28) also quotes Parmenis, Aristotle, Heraclitus and Plato in this sense:

It is, therefore, correct to say that "thinking and Being are identical," 26 and "the scientific understanding of that which is without matter is identical with the thing itself" 27 and "I searched myself," 28 as being one of the Beings. And it is the same with recollections. ${ }^{29}$ 
Thus, the sphere of the Intellect is not, like Aristotle's divine reason, a kind of indistinguishable homogeneity but is, on the contrary, an inherent multiplicity; a clearly distinguished diversity of not only differentiated ideas and forms but also different individually thinking intellects. The Intellect is thus a multitude of objects and subjects, which, however, lie in timeless eternity, in thinking that has the character of eternal contemplation. These ideas (the first things that form the content of the Intellect) are not located anywhere; they are not found in any place; the Intellect (intelligible world) is not somewhere next to, outside or beyond the sensory world in the local sense. Plotinus (1992, V.9.5.33) says: "For they are not outside ( $" \xi \xi \omega)$ Beings nor are they in place, but rather they remain always in themselves not admitting change or destruction. For this reason, they are really Beings." Being out of time (thus beyond change), and independent of contingent creation and destruction makes these ideas real, the first existing entities: "But if they are generated or destroyed, their being will have to be added to them from outside, and they will no longer be Beings, but that which is added will be Being" (V.9.5.35).

It is also just the sphere of the Intellect which (like Plato's realm of ideas) provides eternal paradigms for everything found at the lower metaphysical levels. Sensory things gain their determinacy precisely by participation in eternal paradigms: "Sensibles are indeed what they are said to be by participation, with their underlying nature acquiring a shape from elsewhere..." (V.9.5.37).

So-called intelligible matter plays a specific role at a metaphysical level of the Intellect. It is a kind of model of sensory matter at the level of the sensible world (II.4.5.24, III.8.11.1). Unlike sensory matter, however, intelligible matter does not have shortcomings and is not "evil" (II.4.5.12, II.4.15.17, II.5.3.8). Wallis (1972, 66) points out that although the term "intelligible matter" can be found already in Aristotle's text, ${ }^{30}$ Plotinus uses it in a different sense. There is probably a closer connection with Plato's concept of an undetermined Dyad, which forms part of Plato's unwritten doctrines and is understood as the basis of the theory of ideas (V.1.5.6, V.4.2.7; Reale 1997).

In our opinion, all these considerations support our claim that the Intellect as a hypostasis is clearly separated from the One, and its distinction is, for Plotinus, clear and precise. In the next section, we will proceed with a discussion of the Soul.

\section{THE SOUL}

When considering Plotinus' conception of soul, we must distinguish between the particular soul of an individual person and world soul. At the same time, however, we need to distinguish these meanings from cases where Plotinus talks at a metaphysical level about the Soul as a hypostasis. Plotinus uses three meanings of the term "soul" at various times. While it is obvious that they are internally interconnected, each meaning of this term is associated with different purposes. Plotinus is particularly concerned with the relation of these different forms of soul and their unity in Ennead IV.9 and IV.3. 
Plotinus' metaphysical system localizes the Soul in a relation with the Intellect on one side and the material, sensory world on the other. There is obviously a close connection at both of these points of contact, but, at the same time, Plotinus tries to maintain a clear separation of these hierarchically ordered metaphysical levels.

\section{The world soul}

There are two processes at the lower level of the Soul: on the one hand, the world soul produces the form of the world, giving the material world its shape and content (II.1.5.6), and, on the other hand, the individual human soul enters the human body as an animating element. By giving shape and content to the material world, the world soul transforms a substance without form into a body that has certain qualities, i.e., into qualified bodies ( $\tau$ otóv $\delta \varepsilon \sigma \tilde{\omega} \mu \alpha$ ) (IV.4.18). This is also why we call the world soul "nature" ( $\varphi v ́ \sigma \iota)$ according to Plotinus (1992, VI.4.15.8). There are also interpretations that claim that nature or the lowest part of the Soul could be understood as the fourth hypostasis, but these are not usually considered to be sufficiently substantiated. ${ }^{31}$

The world soul is not composed of individual souls, nor are they parts of it as the Stoics imagined (IV.3.2-3). Although the world soul can be understood as (impersonal) nature, it is itself an individual soul.

This then leads to the notion that both the world soul and the individual soul are a manifestation of a single universal soul, the idea of the soul existing at a higher ontological level (the level of the Intellect) (IV.3.2.1, IV.3.2.54, IV.3.4.14). This is also what brings unity to all souls: "[I]f the soul of the universe and my soul derive from one Soul, then again all souls are one" (IV.9.1.13).

\section{The individual soul}

If we turn our attention to the individual soul, the problem we encounter in Plotinus' philosophy is that, according to his conception, the same individual soul exists in many bodies. ${ }^{32}$ Blumenthal $(1996,85)$ points out that despite Plotinus' attempt to give a satisfactory interpretation of this thesis, it is difficult for him to explain the diversity of particular individuals. Explanation of individual diversity as being due to the influence of matter is unsatisfactory because matter itself has no individualizing characteristics. ${ }^{33}$ Explanation using so-called individual forms then becomes uncertain because it is not clear whether Plotinus accepted the theory of individual forms per se.

Plotinus compares the way the human soul is within the human body to the presence of light (IV.3.22.1) or heat (IV.4.29) in the air, arguing that "[I]t is present as a whole everywhere in the body" (IV.9.1.2). Believing that different parts of the soul are present in different parts of the body is, therefore, wrong: "not having one part of itself in this area of the body, and another in that" (IV.9.1.4).

In some places, Plotinus uses Plato's three-part distinction of the soul (I.2.1.17), but Blumenthal $(1996,87)$ points out that elsewhere he criticizes this division as inadequate. Plotinus also concludes that the two lower parts of the soul do not provide strong enough arguments to explain anger, higher emotions or desires (IV.4.28.1). 
These must be explained not by Platonic division into three parts of the soul but, like Aristotle does, by the concept of desire (ó $\rho \varepsilon \xi 1 \sigma)$, which goes diagonally through this threefold division and manifests itself in different ways at different levels of the soul. In other places, Plotinus also uses Aristotelian division into the vegetative ( $\varphi v \tau \iota \kappa o ́ v)$ part of the soul, the central part of the soul with perception and the higher power of the

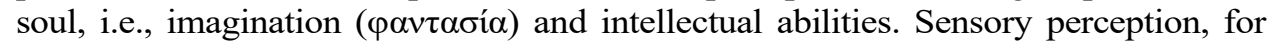
Plotinus, includes all types of sensory stimulation (impression - $\tau$ v́ $\pi$ o ), e.g., seeing or perception of temperature (as well as various inner bodily feelings) (III.6.1.1) and is always directed towards the material world, thus also requiring material sense organs (IV.3.23.3).

The soul is not spatially localizable; only the activities in the body that are determined by it are localizable. ${ }^{34}$ The individual human soul "enters" the body, which is naturally pre-formed with a certain shape and other qualities and characteristics. Similarly, after the death of an individual, the dead body no longer has a human soul, yet it has a certain shape and other qualities, and is a qualified body. Thus, a living person has his own individual soul on one hand, but his body is not completely spiritless material. Rather, it is formed by nature (the world soul). The individual soul is then not homogeneous, and although it is not clear exactly what division of the soul Plotinus accepted, it is clear that he distinguished lower parts of the soul (that were closer to matter and mediated functions related to our body) from higher parts, which, in contrast, were in contact with a higher metaphysical level (the intelligible world of the Intellect). This higher part of the soul is then understood as our uttermost self - our real soul for Plotinus (IV.8.8.1).

The main link between the body, the lower parts of our soul and our higher mental abilities is (according to Plotinus) the imagination ( $\varphi \alpha \nu \tau \alpha \sigma i ́ \alpha)$ (Blumenthal 1996, 88). Through imagination, the soul is related, on the one hand, to physical experiences, feelings and sensory perceptions and, on the other hand, to their grasp by reason and by the intellect-related part of the soul. Imagination has a double nature for Plotinus. One part is dependent on the body and disappears with it; the second part is independent of it. ${ }^{35}$ Similarly, rational practical activity in which reason initiates an action is mediated by the imagination to the lowest components of the soul (VI.8.2). The highest part of the soul then always remains outside matter as in the intelligible world of the Intellect (IV.8.8.1). This part of the soul can, therefore, be understood as the "individual intellect", which is the image of the Intellect as a hypostasis (Blumenthal 1996, 92).

The thinking of the soul then takes place in time and takes the form of a transitioning between objects that are the subject of thought. Plotinus uses the term

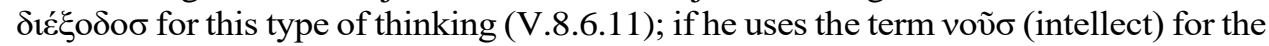
soul in a similar context, he complements it with the term "discursive" ( (VI.9.5.7) or "dividing” ( $\mu \varepsilon \rho i ́ \zeta \omega v)$ (V.9.8.21). Plotinus, however, always considers this discursive, rational thinking to be at a lower level than pure insight occurring at the level of the Intellect.

Different meanings assigned to the term "soul" are, in our opinion, the main reason for confusion over the relations of hypostases. While a desire (ö $\rho \varepsilon \xi 1 \sigma)$ may go 
diagonally through different metaphysical levels and something similar may be true in terms of an individual soul (which animates a body at the level of sensible matter but stretches up to the level of the Intellect or even higher), the Soul as a hypostasis is well defined and does not overlap with other metaphysical levels. Still, the hypostases are mutually related in different ways, and we summarize these relations and the differences between them in the following section.

\section{DIFFERENTIATIONS OF HYPOSTASES}

There are different interpretations of mutual relationships and the differences between hypostases. We firstly summarize some existing views on this issue and then, in the following passages, describe our alternative account of the fundamental differentiators of the One, the Intellect and the Soul.

Banner (2018, 194), Mazur (2005) and Mortley $(1975,376)$ propose what has been called the "axiom of continuous hierarchy" - a principle which takes it as a given that "[T]here can be no breaks in the chain of being." This interpretation emphasizes the integral wholeness of all reality, where all metaphysical levels are linked or even intimately connected. The hypostases overlap, and there are no breaks in the continuity of reality. These authors also further the idea of unity not only of the One itself but also of the whole produced reality, which is understood as structured unity or unity-inmultiplicity, where all things are interconnected by unseen links. All souls are connected with all parts of the cosmos through cosmic sympathy, which provides not only perception by the senses but also the functionality of magical rituals (Banner 2018, 195).

In contrast, Armstrong (1940, 24) and Heinemann (1921, 122-23) claim that in the early stages (the first five treatises of Enneads) of development of his philosophical system, Plotinus has not yet arrived at a clear distinction between the One and the Intellect, so the borderlines between these two hypostases are blurred in some parts of these early texts. ${ }^{36}$ However, Armstrong and Heinemann agree that in the later parts of Enneads (which present Plotinus' mature and fully developed account of hypostases) there are clear distinctions between them. Some authors such as Rist $(1967,41)$ do not even agree with this separation of Plotinus' thought into stages and try to show that even these early passages of Plotinus' text can be shown to be fully consistent with his later philosophy.

In a similar vein, Corrigan $(2005,24)$ does not recognize the separation of lines between different hypostases in certain places. He claims that in several parts of Plotinus' text it seems that the intelligible world reaches deeply into the world of matter. Soul is then described as an amphibious traveler between the intelligible and sensible worlds or an inhabitant of both. However, he acknowledges that in other passages, the division between hypostases is stated much more sharply, so a definite picture of Plotinus' metaphysical structure may have very precisely defined contours.

In the following paragraphs, we will describe our understanding of the relations and differentiations of hypostases. We claim that in the context of Plotinus' mature philosophy, the hypostases do not overlap, and there are no blurred borders between them. Although some parts of his texts may be more poetical or metaphorical (thus 
possibly presenting a confusing picture of the hypostases), in Plotinus' core philosophy, the hypostases are clearly separated and defined, and they relate to each other in precisely formulated terms.

\section{Mutual relations of hypostases}

Let us firstly consider ontological production and what it implies regarding the nature of the mutual relations of hypostases. Because hypostases produce less perfect degrees of reality completely spontaneously and remain unchanged by this production, they are also completely independent of inferior degrees of reality and do not relate to them in any way. Thus, with the exception of spontaneous production ( $\left.\pi \rho{ }^{\circ} \circ \delta \sigma \sigma\right)$, there is no relation between higher degrees of reality and lower ones. Plotinus initially says that the One has no relation to its products; that even if, on one hand, its products did not exist at all, it would still have no effect on the One and even if, on the other hand, the One had emanated one more universe (V.5.12.40). It is, therefore, impossible to interpret Plotinus' conception as pantheism because (as Plotinus says in the same place) if the One (God) is everything, then it would also depend on everything. But the One in its being transcends everything. In other words, while producing everything, it is at the same time completely independent of everything. Lower degrees of existence do not touch the One in any way; they leave it without any interest (metaphorically speaking) - "[T] he One has no need of Intellect" (V.1.6.42). ${ }^{37}$ Generally, ontological production in the context of Plotinus' mature philosophy leaves no space for any overlapping between the One and the Intellect or their blurred borderlines. Production neither requires it nor implies it.

In the opposite direction, the situation is similar. From lower levels of being to

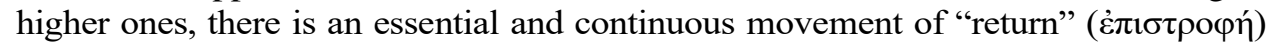
(see Figure 2). This backwards movement in which the product turns towards its source is the movement in which the product acquires form and order. At the same time, with regard to Plato's $(1967,254 \mathrm{c}-\mathrm{e})$ concept of supreme genera $(\mu \varepsilon \dot{\gamma} \gamma \sigma \tau \alpha \gamma \varepsilon$ ć $\eta$ - being, stillness, movement, identity and diversity), Plotinus assigns two productive genera to the productive flow from the One (movement and diversity) and two formative genera (stillness and identity) to the returning flow. Vision plays an important role in this process of return because seeing a sensory object can lead us to the idea of this object (or even higher during contemplation), thus providing its form (III.8.7). As in the previous case, the movement of return does not presuppose or imply any kind of overlap or blurring of borders between hypostases.

Furthermore, none of the hypostases have "knowledge" of lower degrees of reality. The One is beyond any knowledge (VI.7.39.19), and the Intellect is in a state of eternal contemplation of its own fixed principles so cannot, in any way, relate in its thinking to a changing world at lower levels of reality. The only candidate for knowledge of lower levels of reality, therefore, remains the Soul. Here, Plotinus merely says that the world soul "knows" only about cosmic history in its entirety in terms of its own principles, not in terms of specific events (IV.4.9.16, V.8.3.26). For Plotinus, these hypostases' ignorance of lower levels of reality is not a lack thereof 
since they always have a higher type of knowledge in themselves, so the absence of an imperfect picture within these higher forms of knowledge cannot be considered a deficiency (III.8.4.43, IV.4.8.3). This also confirms our thesis of the ontological separation of hypostases.

The relationship of hypostases also plays a role in Plotinus' explanation of paranormal phenomena and the structure of soul (Wallis 1972, 70). Since the world (with the exception of the dark mass of matter) is a living organism, events in one part of it trigger responses in other parts (II.3.7, IV.4.32). For example, prayer to divine beings cannot affect their consciousness as they are absorbed in eternal contemplation at the level of the Intellect, but it can influence lower parts of an individual soul, and thus it can achieve the fulfillment of a request made through prayer (IV.4.40.27). Likewise, Plotinus explains the relationship between the inner moral character of an individual's soul and the image of this character that can be seen in his eyes, and the relationship between man's destiny and the movements of stars (II.3.7.4). This connection, however, applies only to lower parts of the human soul; the highest part of the human soul (existing at the level of the Intellect) is independent of the movements of stars and, in this respect, free (II.3.9.14, IV.4.39.1). Similarly, Plotinus believed that all magical practices work only at the level of lower parts of the soul, the highest part of the soul, therefore, being unreachable and inviolable (II.9.14.1). Therefore, the highest self of man cannot be endangered by these practices, but, at the same time, they cannot help him in his spiritual endeavors (IV.4.43).

These views of Plotinus contrast with the practices of late Neoplatonism, which shifted from philosophy to theurgical rituals (Merlan 1953; Armstrong 1955). It may also seem that discussion of different parts of soul may contradict our thesis that hypostases are clearly separated. However, this discussion is related to the individual soul of human being, which may span several metaphysical levels. This is quite common in Plotinus. Sensible living beings comprise matter but also always have an individual soul and, at the same time, reflect some form from the world of ineligibles - the Intellect. This, nonetheless, does not contradict the thesis that hypostases as such are clearly defined and separated.

\section{Differentiations of hypostases}

Table 1 shows our interpretation of the relationships of hypostases in Plotinus. At the level of each hypostasis, a new metaphysical factor enters the ontological picture. At the level of the Intellect, multiplicity is established; at the level of the Soul, time is introduced; and, at the level of dark matter, dimensional space is constituted. These ontological differentiators then penetrate lower ontological levels (to lower hypostases) but in altered form. The key stages of production, therefore, comprise the entirety of unfolding spatio-temporal reality with its multiplicity of existing entities.

Multiplicity is firstly introduced with production of the Intellect. This is also why the Intellect is sometimes identified with the Dyad (V.4.2.4-10, VI.6.3.12-15). The Dyad is the most elementary form of multiplicity and, therefore, in the primary role as the 


\begin{tabular}{l|ccc}
\hline The One & Unity & \\
Intellect & Multiplicity & Eternity & \\
Soul & & Temporality & Non- \\
& & & dimensionality \\
Matter & & Dimensionality \\
\hline
\end{tabular}

Table 1: Ontological differences of hypostases

product of the One: "Before the Dyad is the One; the Dyad is second and, having come from the One, the One imposes definiteness on it, whereas it is in itself indefinite" (V.1.5.6). The Dyad is the term from Plato's philosophy associated with his unwritten teachings and used extensively by his followers (Rist 1962). The existence of the Intellect is essentially a numerical difference because interaction between the One and the Dyad produces definitiveness. The One and the Dyad produce numerically different, definite Forms: "But whereas the Dyad, understood as a sort of substrate, is indefinite, each Number that comes from it and the One is a Form, Intellect in a way having been shaped by the Forms that come to be in it" (V.1.5.14). Definite, numerically different Forms are then substances: "When it has been made definite, it is henceforth Number, Number as Substance" (V.1.5.7). All other things at lower metaphysical levels are also numerically different, starting with the Soul: "Soul, too, is Number" (V.1.5.9). There is of course a difference between how the Intellect and Soul relate to multiplicity. In terms of their relationship to multiplicity, Plotinus says that the Intellect is a unity in multiplicity ( $\varepsilon \tilde{\imath} \sigma \kappa \alpha i$ i $\pi \circ \lambda \lambda o$ í), while the Soul is a

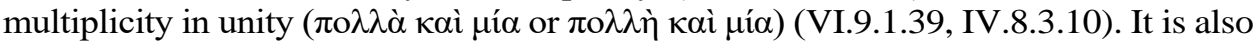
worth noting that multiplicity is connected to Plotinus' diversity and identity genera.

Time manifests fully only at the level of the Soul. The intellect is eternal, beyond any temporality - i.e., not just lasting in all moments: "Before and after in Forms does not consist in time, and the intellection of before and after will not be in time either" (IV.4.1.25). On the other hand, the Soul is in time. It is temporal, although it always exists, i.e., at all moments in time. Its existence is tied to time (Wallis 1972, 53).

The difference between the timeless thinking of the Intellect and temporal thinking of the Soul in Plotinus has already been mentioned above. While the Intellect sees its objects (ideas) in timeless contemplation, the Soul thinks discoursefully, in propositions, syllogistically in a structured way.

Clearly, it is not possible to speak in temporal expressions at the level of the One and the Intellect. Their existence has the character of timeless eternity. Although its metaphysical level brings time to the scene, the Soul is itself eternal as a hypostasis. Thus, Plotinus understands the world as eternally existing (even the sensory world), so the interpretation we find in Plato's Timaios dialogue (which describes the temporal origin of the sensory world) cannot be taken literally according to Plotinus' interpretation. ${ }^{38}$ We must again note that time at the level of the Soul is linked with movement, Plotinus' primary genera.

Finally, there is the level of the sensible Cosmos that introduces dimensional spatiality. Matter itself does not possess magnitude (II.4.9.1, II.4.8.10). It has to be 
provided along with other qualities by a form, producing a sensible object with magnitude and mass that is located in dimensional space. The spatio-temporal dimension of sensible objects is produced by the interaction of these principles at the metaphysical level of matter.

\section{CONCLUDING REMARKS}

Plotinus' metaphysical system is underpinned by several basic ideas or principles which carry the bulk of its structure and can also serve as interpretative keys to questions that may challenge readers (if they want to understand some of the more difficult parts of his work). We now show that the thesis put forward in previous sections is in full compliance with these principles.

The basic principle of Plotinus' metaphysics is the principle of unity in multiplicity. Just as the whole of the universe is, by its basic structure, a counterposition of the One and the multiplicity of the world, so within each of the hypostases, the underlying organizing principle is some diversified multiplicity which forms, in some respects, a unity. The Intellect is both a multiplicity of individual forms and their unity. The Soul is the multiplicity of individual souls, the uniform world soul and their unity, constituted by the common form of the universal soul. Similarly, in its diversity, the world of sensory forms creates unity as a result. However, this does not imply that the multiplicity forming the unity is not distinct, that there are overlaps or unclear distinctions. Unity, in this sense, comprises the multiplicity of precisely defined entities.

Another such principle is that the produced is always an imperfect image of the producer, yet the producer can be (imperfectly) known from its product. ${ }^{39}$ For Plotinus, this principle seems to be an axiom based on observed imperfection in the world and the need to explain this (Proclus 1963, §7). The way to explain it is then to place perfect forms (the first things) into the sphere of the Intellect: "For anything which is first is not a sensible. For the form in sensibles that is over and above their matter is an image of the real Form, and all form that is present in something else comes to it from something else, and is an image of that from which it comes" (V .9.5.17). This principle is fully in accordance with our thesis of precisely defined hypostases - imperfect lower-being images of higher entities, both of which are precisely distinct.

The specific principle of Plotinus' thought is the omnipresence of life. The whole universe is made up of one large organism. ${ }^{40}$ At the higher level, it is the Intellect, which is a living totality of living forms, and, similarly, it is also at the level of the Soul. The formless, dark sensory material is inanimate, but we always encounter it in a formed state, and it is undoubtedly given form by the living world soul. Similarly, the One cannot be said to be either alive or inanimate because of the impossibility of attributing to it any characteristics derived from lower levels of existence. Yet, based on the principle that what is produced is an imperfect image of the producer, the One is, in a higher sense, very alive. Still, this does not mean that the permeating liveness of all levels produces, requires or implies blurred borders between hypostases. Again, in this case, life is present at all levels in a different sense, and it does not contradict the thesis that all metaphysical levels are precisely distinct and well defined. 
We may conclude that in the context of Plotinus' mature philosophy, the hypostases do not overlap, and there are no blurred borders between them. Although some parts of his texts may be challenging to interpret and may provide a confusing picture to some readers, in Plotinus' core philosophy, the hypostases are clearly separated and defined, and they relate to each other in precisely formulated terms.

\section{NOTES}

1. This article is extended version of a research published in Czech language in (Vacura 2013).

2. Plotinus attacked Gnostics, e.g., in the Enneads, II.9.6.24-8. In this text we use edition (Plotinus 1992) when quoting from the Enneads and henceforth we will omit repeating "Plotinus 1992" and use only standard paragraph numbers in quotations from this work, e.g., just (II.9.6.24-8).

3. Plotinus believed that the passage in Plato's Second Epistle concerning the "King of All" referred to the three hypostases. See Banner $(2018,69)$.

4. On the idea of a chain of being, see Lovejoy (1936).

5. With the focus of our text in mind, we note that in Aristotle's theory there were no overlaps or blurred borders between substances and accidents.

6. See Plotinus' Enneads V.4.1.5; Plotinus here follows Plato (2017b, 509b) who says in the sixth book of Republic: "[T]hen, you are to say that the objects of knowledge not only receive from the presence of the good their being known, but their very existence and essence is derived to them from it, though the good itself is not

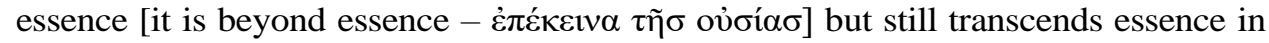

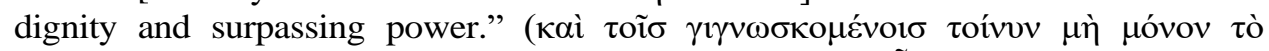

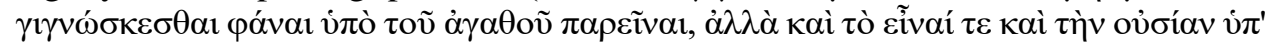

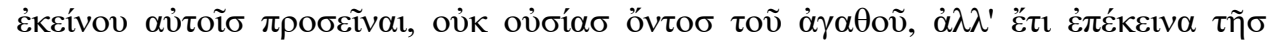

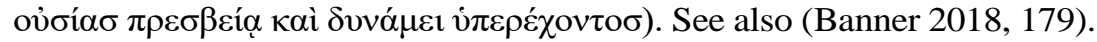

7. We write the names of the hypostases (Soul, Intellect and One) with a capital letter.

8. We remind again that in this text we use edition (Plotinus 1992) of Plotinus' Enneads and henceforth we will omit repeating "Plotinus 1992" and use only standard paragraph numbers in quotations from this work, e.g., just (V.3.13.7, 14.1).

9. Plotinus follows Plato's VII. letter where he says "For it does not at all admit of verbal expression like other studies, but, as a result of continued application to the subject itself and communion therewith, it is brought to birth in the soul on a sudden, as light that is kindled by a leaping spark, and thereafter it nourishes itself." (Plato 1989a, 341c5). See also (VI.9.4.11) and Gkaleas (2018).

10. The One does not have internal relations other than some internal "to-selfrelatedness" (VI.8.14.25), which, for example, Bussanich (1996, 45) again recommends should not be understood as a relationship of some internal components of the One, a way of emphasizing the absence of a relationship to something else. Similarly, it is not to be taken literally that the One is the cause of itself (VI.8.13.55, VI.8.14.41, VI.8.16.14), which is better understood as the One having no external or other cause outside itself. 
11. (VI.8.20.9). This concept of the all-encompassing nature of the One follows Aristotle's concept of perfectness: "But that of which no part is outside, is complete and whole: that is how we define 'whole', as meaning that of which no part is absent. (...)" (Aristotle 1983, 207a9). See also Bussanich (1996, 44).

12. See variations on this topic in the Enneads I.7.1, IV.7.23.7, VI.9.6.16, VI.7.24.13, VI.7.41.28, VI.9.6.39.

13. See different approaches to this question in the Enneads III.8.11.40, V.2.1.7, V.2.1.13, V.3.15.28, V.3.17.12, V.5.5.5, VI.6.13.50, VI.7.32.2, VI.8.19.12.

14. See discussion in Wallis $(1972,61)$ and Plotinus (1992, IV.5.6, II.1.7.26, I.1.4.12, IV.3.22.1).

15. According to Anatolius (the Aristotelian professor at Alexandria who became bishop of Laodicea in about 268), quoted from Armstrong $(1967,242)$.

16. This conclusion may seem paradoxical, but Plato (1989b, 30c, 39e) says in Timaeus that the universe would be incomplete if it did not contain all possible living creatures. The historical analysis of this idea, which is called the principle of multiplicity and relates to the so-called great chain of being, is provided by Lovejoy (1936).

17. See variations of this topic in the Enneads, II.9.13.1, II.9.13.25, III.2.14.6, III.3.3.

18. See Plato's Timaeus (Plato 1989b, 29e-30a).

19. In this context, Wallis draws attention to the debate on the relationship between Plotinus' $\alpha \varphi \theta$ oví $\alpha$ and the later attribution of love to the Christian God. These claims are supported by several of Plotinus' references to love in connection with the One (e.g., VI.8.13.5, VI.8.15.1). The problem, however, is that love implies need, but the One has no need or desire (III.5.7.9). See Wallis $(1972,64)$.

20. See analyses of this topic in the Enneads III.2.14.1, VI.2.21.32, VI.7.1.28, VI.8.17.1). See also discussion by Wallis $(1972,63)$.

21. See variations in the Enneads III.6.6.10-17, V.1.4.1, V.3.16.29, V.1.10.12, II.5.3.31, VI.2.20, V.3.13.1, V.7.1, VI.5.12, VI.6.18.

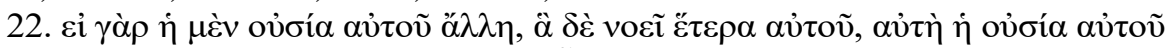

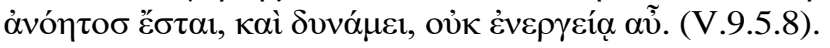

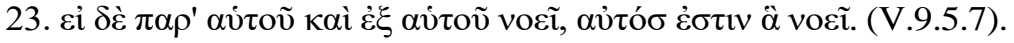

24. See (Aristotle 2017, 431a1; 2016, 1074b15).

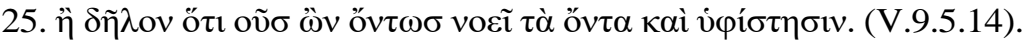

26. Parm. fr. B 3, (Diels and Kranz 1952).

27. See (Aristotle 2017, 430a3, 431a1).

28. Heracl. fr. B 101, (Diels and Kranz 1952).

29. See (Plato 2017a, 72e5).

30. See (Aristotle 2016, 1036a9, 1037a4, 1045a34).

31. Plotinus' Enneads V.2.1. See also Blumethal (1996, 11). For comparison with Aristotle's Conception of Nature see (III.8.2, IV.4.12, V.2.1.18).

32. For details of this debate, see Plotinus' Ennead V.9 ("Whether all souls are one soul").

33. This is the according to some interpretations and explanations of Aristotle. See the discussion in (Irwin 1988, 248-68; Lloyd 1981, 1-48). 
34. Plotinus also discusses the problem of Plato's conception of the soul: it is immaterial, but each of its three parts is located in a different part of the body. See Blumenthal $(1996,84)$.

35. The problem for Plotinus is the question of memory after death. See IV.4.1.1, IV.3.31.8.

36. For criticism, see Blumenthal (1996, 205).

37. These propositions are another reason to question Plotinus' interpretation of the One as being the Christian God who always refers to the created world with love.

38. For discussion see Hadot $(1993,38)$ and III.2.1.20, IV.3.9.12, VI.7.3.1.

39. Wallis points out that Plotinus does not explain why the product must always be less perfect than the producer. See Wallis $(1972,60)$.

40 . Here, we can recall the doctrine of "cosmic sympathy" ( $\sigma 0 \mu \pi \alpha \dot{\theta} \theta 1 \alpha)-$ the organic interconnection of all cosmic events associated with the Stoic philosopher Poseidonius (135-51 BC).

\section{REFERENCES}

Aristotle. 1983. Physics: Books III and IV. Translated by Edward Hussey. Oxford: Clarendon Press.

Aristotle. 2016. Metaphysics. Translated by W. D. Ross. Cambridge: Hackett Publishing.

Aristotle. 2017. De anima. Translated by C. D. C. Reeve. Cambridge: Hackett Publishing.

Armstrong, Arthur Hilary. 1940. The architecture of the intelligible universe in the philosophy of Plotinus. Cambridge Classical Studies 6. Cambridge: Cambridge University Press.

Armstrong, Arthur Hilary. 1955. Was Plotinus a magician? Phronesis I, no. I: 73-7973-79.

Armstrong, Arthur Hilary. 1967. The Cambridge history of later Greek and early medieval philosophy. Cambridge: Cambridge University Press.

Banner, Nicholas. 2018. Philosophic silence and the "one” in Plotinus. Cambridge, New York: Cambridge University Press.

Blumenthal, Henry J. 1996. On soul and intellect. In The Cambridge Companion to Plotinus. Edited by Lloyd P. Gerson. Cambridge: Cambridge University Press.

Bussanich, John. 1996. Plotinus's Metaphysics of the One. In The Cambridge Companion to Plotinus. Edited by Lloyd P. Gerson. Cambridge: Cambridge University Press.

Corrigan, Kevin. 2005. Reading Plotinus: A practical introduction to neoplatonism. Purdue University Press.

Diels, Hermann Alexander, and Walther Kranz. 1952. Die fragmente der vorsokratiker. Weidmann.

Gkaleas, Konstantinos. 2018. Republic, Plato's 7th letter and the concept of $\Delta \omega \rho \imath \sigma \tau i$

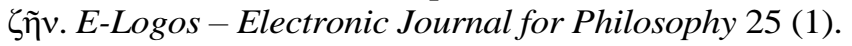


Hadot, Pierre. 1993. Plotinus or the simplicity of vision. Chicago and London: The University of Chicago Press.

Heinemann, Fritz. 1921. Plotin: Forschungen über die Plotinische frage, Plotins entwicklung und sein system. Leipzig: F. Meiner.

Irwin, Terence H. 1988. Aristotle's first principles. Clarendon Press.

Lloyd, Anthony C. 1981. Form and universal in Aristotle. Francis Cairns.

Lovejoy, A. O. 1936. The great chain of being. Harvard University Press.

Mazur, Zeke. 2005. Plotinus' philosophical opposition to gnosticism and the implicit axiom of continuous hierarchy. In History of Platonism: Plato Redivivus. Edited by Robert Berchman and John Finamore. University Press of the South.

Menn, Stephen. 1992. Aristotle and Plato on God as nous and as the good. The Review of Metaphysics 45 (3): 543-73.

Merlan, Philip. 1953. Plotinus and magic. Isis XLIV (4): 341-348-341-348.

Mortley, Raoul. 1975. Negative theology and abstraction in Plotinus. The American Journal of Philology 96 (4): 363-77.

O’Meara, Dominic. 1996. The hierarchical ordering of reality in Plotinus.' In The Cambridge Companion to Plotinus. Edited by Lloyd P. Gerson. Cambridge: Cambridge University Press.

Plato. 1967. Sophist. In Theaetetus, Sophist, by Plato, translated by H. N. Fowler. Cambridge: Harvard University Press.

Plato. 1989a. Epistles. In Timaeus, Critias, Cleitophon, Menexenus, Epistles, by Plato. Translated by R. G. Bury. Cambridge: Harvard University Press.

Plato. 1989b. Timaeus. In Timaeus, Critias, Cleitophon, Menexenus, Epistles, by Plato. Translated by R. G. Bury. Cambridge: Harvard University Press.

Plato. 2017a. Phaedo. In Euthyphro, Apology, Crito, Phaedo, by Plato. Translated by Chris Emlyn-Jones and William Preddy. Cambridge: Harvard University Press.

Plato. 2017b. The republic. Edited by G. R. F. Ferrari. Translated by Tom Griffith. Cambridge: Cambridge University Press.

Plotinus. 1992. The Enneads. Translated by Stephen MacKenna. London: Larson Publications.

Porphyry. 2017. "Life of Plotinus." In The Enneads, by Plotinus. Translated by Lloyd P. Gerson. Cambridge: Cambridge University Press.

Proclus. 1963. The elements of theology. Clarendon Press.

Reale, Giovanni. 1997. Toward a new interpretation of Plato. Washington: The Catholic University of America Press.

Rist, John M. 1962. The indefinite dyad and intelligible matter in Plotinus. The Classical Quarterly 12 (1): 99-107.

Rist, John M. 1967. Plotinus: The road to reality. Cambridge University Press.

Robinson, T. M. 1967. Demiurge and world soul in Plato's Politicus. The American Journal of Philology 88 (1): 57-66. https://doi.org/10.2307/292727.

Vacura, Miroslav. 2013. Základní struktura Plótínovy metafyziky. E-Logos Electronic Journal for Philosophy 19 (10).

Wallis, Richard T. 1972. Neoplatonism. Hackett Publishing.

Submitted: 28 November, 2019; revised: 1 May 2020 